\title{
PENGARUH BIAYA AGENSI, KESEMPATAN INVESTASI, HUTANG, LIKUIDITAS, PROFITABILITAS, DAN UKURAN PERUSAHAAN TERHADAP DIVIDEND PAYOUT RATIO
}

\author{
Purweni Widhianningrum \\ Pendidikan Akuntansi IKIP PGRI Madiun
}

\begin{abstract}
The purpose of this research is to to determine the effect of agency costs (which is proxied by managerial ownership and institutional ownership), investment opportunities (which is proxied by firm age, market to book value and growth), debt, liquidity, profitability, and firm size on dividend payout ratio. The reseach is used manufacturing companies listed in IDX for periode 2003 until 2007 for object research, with total of population 151 companies. The method of data collection is done by using polling data method and give 205 total observation. Analysis method that use in this research is multiple regression analysis. The result of this reseach show that managerial ownership, institusional ownership, age of the firms, market to book value, growth, debt to equity ratio, current ratio, return on asset and size of the firms simultanous have positive influences to devidend payout ratio. For partial influences, managerial ownership, age of the firms, debt to equity ratio, current ratio, return on asset and size of the firms have positive influences, and institusional ownership, market to book value, growth have negative influences to dividend payout ratio. Debt to equity ratio have a dominant influences to dividend payout ratio.
\end{abstract}

Keywords: dividend payout ratio, managerial ownership, institusional ownership, age of the firms, market to book value, growth, debt to equity ratio, current ratio, return on asset, firm size, multiple regression analysis.

\begin{abstract}
ABSTRAK
Penelitian ini bertujuan untuk mengetahui pengaruh dari biaya agensi (yang diproksikan dengan kepemilikan manajerial dan kepemilikan institusi), kesempatan investasi (yang diproksikan dengan umur perusahaan, market to book value dan growth), hutang, likuiditas, profitabilitas, dan ukuran perusahaan terhadap dividend payout ratio. Penelitian ini menggunakan obyek penelitian pada perusahaan manufaktur yang masih terdaftar di Bursa Efek Indonesia periode 2003 sampai 2007, dengan jumlah populasi sebanyak 151 perusahaan. Dengan menggunakan metode pengumpulan data secara pooled data, maka didapatkan total observasi sebanyak 205 pengamatan. Metode analisis yang digunakan adalah regresi berganda. Temuan penelitian menunjukkan bahwa kepemilikan manajerial, kepemilikan institusi, umur perusahaan, market to book value, growth, debt to equity ratio, current ratio, return on asset, ukuran perusahaan secara simultan berpengaruh positif terhadap dividend payout ratio. Sedangkan secara parsial kepemilikan manajerial, umur perusahaan, debt to equity ratio, current ratio, return on asset, ukuran perusahaan menunjukkan pengaruh positif, dan kepemilikan institusi, market to book value dan growth menunjukkan pengaruh yang negatif terhadap dividend payout ratio. Debt to equity ratio berpengaruh dominan terhadap dividend payout ratio.
\end{abstract}

Kata kunci: dividend payout ratio, kepemilikan manajerial, kepemilikan institusional, umur perusahaan, market to book value, growth, debt to equity ratio, current ratio, return on asset, ukuran perusahaan, analisis regresi bergada. 


\section{A. PENDAHULUAN}

Kebijakan dividen merupakan keputusan tentang seberapa banyak laba saat ini yang akan dibayarkan sebagai dividen daripada ditahan untuk diinvestasikan kembali dalam perusahaan. Laba yang ditahan merupakan salah satu sumber dana terpenting untuk membiayai pertumbuhan perusahaan, tetapi dividen membentuk arus kas yang semakin banyak mengalir ke tangan para pemegang saham (Brigham dan Houston, 2001:27).

Kebijakan pembayaran dividen memberikan dampak penting dalam suatu perusahaan karena melibatkan kepentingan berbagai pihak seperti pemegang saham, manajer dan kreditor. Pada umumnya pemegang saham mempunyai tujuan utama meningkatkan kesejahteraannya yaitu dengan mengharapkan return dari dana yang telah diinvestasikan dalam bentuk dividen maupun capital gain. Dilain pihak, manajer juga mengharapkan adanya pertumbuhan secara terus menerus untuk mempertahankan kelangsungan hidup perusahaan, yang sekaligus juga harus memberi kesejahteraan yang lebih besar kepada para pemegang sahamnya melalui kewenangan yang diberikan untuk membuat keputusan baik berupa keputusan investasi, pendanaan maupun dividen. Kreditor memerlukan informasi tentang kebijakan dividen suatu perusahaan untuk menilai dan menganalisa tentang kemungkinan return yang akan ia peroleh apabila memberikan pinjaman kepada suatu perusahaan.

Penelitian mengenai kebijakan dividen telah banyak dilakukan oleh peneliti terdahulu. Penelitian tersebut pada umumnya ingin mengetahui faktor-faktor apa saja yang dapat mempengaruhi kebijakan pembayaran dividen perusahaan dan dari hasil penelitian terdahulu ditemukan hasil yang berbeda-beda. Perbedaan mengenai hasil penelitian tersebut dikarenakan adanya perbedaan objek serta variabel yang digunakan. Untuk memperoleh penjelasan yang lebih jelas mengenai pembayaran dividen perusahaan di suatu negara maka perlu dilakukan kembali studi tentang kebijakan dividen.

Penelitian ini mengacu serta mengembangkan beberapa variabel yang digunakan pada studi empiris Al-Malkawi (2008) yang berjudul "Factors Influencing Corporate Dividend Decision: Evidence from Jordanian Panel Data" , dengan obyek penelitian perusahaan manufaktur yang terdaftar di Bursa Efek Indonesia selama periode tahun 2003 sampai 2007. Karakteristik obyek penelitian yang digunakan pada penelitian ini dengan penelitian Al-Malkawi (2008) memiliki beberapa kesamaan, yaitu Amman Stock Exchange dan Bursa Efek Indonesia merupakan pasar modal yang sedang berkembang dimana keduanya memiliki struktur kepemilikan yang terkonsentrasi, ukuran perusahaan yang relatif kecil, lebih banyak campur tangan pemerintah dan sebagian besar investor adalah pihak bank.

Pada penelitian Al-Malkawi (2008), variabel-variabel yang digunakan untuk melihat pengaruh terhadap kebijakan dividen adalah insider ownership, ukuran perusahaan, profitabilitas, hutang, growth dan umur perusahaan. Sedangkan dalam penelitian ini menambahkan kepemilikan institusi pada variabel biaya agensi, market to book value pada variabel kesempatan investasi dan variabel likuiditas. Dengan demikian variabel-variabel yang digunakan dalam penelitian ini terdiri dari biaya agensi (yang diproksikan dengan kepemilikan manajerial dan kepemilikan institusi), kesempatan investasi (yang diproksikan dengan umur perusahaan, market to book value dan growth), hutang, likuiditas, profitabilitas, dan ukuran perusahaan.

Berdasarkan uraian latar belakang di atas, maka permasalahan dalam penelitian ini dapat dirumuskan sebagai berikut: 
1. Apakah biaya agensi (yang diproksikan dengan kepemilikan manajerial dan kepemilikan institusi), kesempatan investasi (yang diproksikan dengan umur perusahaan, market to book value dan growth), hutang, likuiditas, profitabilitas, dan ukuran perusahaan berpengaruh signifikan secara simultan terhadap dividend payout ratio?

2. Apakah biaya agensi (yang diprkosikan dengan kepemilikan manajerial dan kepemilikan institusi), kesempatan investasi (yang diproksikan dengan umur perusahaan, market to book value dan growth), hutang, likuiditas, profitabilitas, dan ukuran perusahaan berpengaruh signifikan secara parsial terhadap dividend payout ratio?

3. Diantara variabel-variabel biaya agensi (yang diprkosikan dengan kepemilikan manajerial dan kepemilikan institusi), kesempatan investasi (yang diproksikan dengan umur perusahaan, market to book value dan growth), hutang, likuiditas, profitabilitas, dan ukuran perusahaan, variabel manakah yang dominan mempengaruhi dividend payout ratio?

\section{B. TINJAUAN PUSTAKA}

\section{Teori Kebijakan Dividen}

a. Dividend Irrelevance Theory

Teori ini dikemukakan oleh Modigliani dan Miller (1961), yang memberikan argumentasi bahwa pembagian laba dalam bentuk deviden tidak relevan dengan peningkatan kemakmuran atau kekayaan pemegang saham. Karena dividend pay out ratio hanya merupakan bagian kecil dari keputusan pendanaan perusahaan, nilai perusahaan ditentukan sendiri oleh kemampuan aktiva perusahaan untuk menghasilkan laba atau kebijakan investasi.

Pernyataan Modigliani dan Miller (1961) ini didasarkan pada beberapa asumsi penting yang "lemah" seperti :

1) Pasar modal sempurna dimana semua investor adalah rasional.

2) Tidak ada biaya emisi saham baru jika perusahaan menerbitkan saham baru.

3) Tidak ada pajak

4) Kebijakan investasi perusahaan tidak berubah.

b. Bird in the Hand Theory

Gordon (1962) dan Lintner (1963) menyatakan bahwa biaya modal sendiri perusahaan akan naik jika dividend payout ratio rendah karena investor lebih suka menerima dividen dari pada capital gains. Menurut mereka, investor memandang dividend lebih pasti dari pada capital gains. Hal ini dikarenakan dividen diterima menurut dasar periode berjalan sementara prospek realisasi keuntungan modal diperoleh di masa depan, artinya untuk memperoleh capital gain harus berani untuk berspekulasi bahwa harga saham yang akan datang lebih besar daripada harga saham pada waktu pembelian sehingga dividen dianggap lebih baik daripada capital gain.

c. Tax Preference Theory

Teori ini diajukan oleh Litzenberger dan Ramaswamy (1982). Menurut teori ini investor lebih menyukai perusahaan yang membayar dividen lebih rendah daripada perusahaan yang membayar dividen lebih tinggi. Adanya pajak terhadap keuntungan dividen dan capital gains membuat para investor lebih menyukai capital gains karena dapat menunda pembayaran pajak. 


\section{d. Signaling Theory}

Teori ini menjelaskan bahwa informasi tentang cash dividend yang dibayarkan dianggap investor sebagai sinyal prospek perusahaan di masa mendatang. Adanya anggapan ini disebabkan terjadinya asymetric information antara manajer dan investor, sehingga para investor menggunakan kebijakan dividen sebagai sinyal tentang prospek perusahaan. Apabila terjadi kenaikan dividen yang lebih tinggi dari yang diharapkan akan dianggap oleh investor sebagai sinyal bahwa perusahaan mengalami pertumbuhan laba yang baik. Sebaliknya penurunan dividen akan menjadi sinyal pertumbuhan laba yang buruk pada masa yang akan datang (Bhattacharya ,1979).

\section{e. Clintelle Effect}

Teori ini menyatakan bahwa kelompok (clientele) pemegang saham yang berbeda akan memiliki preferensi yang berbeda terhadap kebijakan dividen perusahaan. Pettit (1977) dalam Wirjono (2003:160) mengklasifikasikan pemegang saham kedalam beberapa kelompok, dimana kelompok-kelompok yang berbeda (different groups) atau clienteles dari pemegang saham menyukai kebijakan pembayaran dividen yang berbeda.

\section{Teori Agensi}

Jensen dan Meckling (1976:5) mendefinisikan hubungan keagenan sebagai sebuah kontrak dimana satu atau lebih pemberi kerja (principal) menyewa orang lain (agent) untuk melakukan beberapa jasa untuk kepentingan mereka dengan mendelegasikan beberapa wewenang untuk membuat keputusan kepada agent. Berdasarkan pernyataan diatas, sudah seharusnya manajer sebagai agent bertindak sesuai dengan keinginan pemegang saham (principal), yaitu memaksimumkan kesejahteraan pemegang saham. Namun pada kenyataannya, dalam menjalankan tugas manajerialnya, manajemen memiliki tujuan pribadi yang bertentangan dengan tujuan pemegang saham. Perbedaan kepentingan antara manajer (agent) dan principal ini akan memicu timbulnya masalah keagenan (agency problem) yang disebabkan adanya pemisahan fungsi antara kepemilikan dan pengedalian perusahaan. Masalah ini timbul karena adanya kecenderungan dari manajemen untuk melakukan moral hazard dalam memaksimalkan kepentingannya sendiri dengan mengorbankan kepentingan pihak principal.

\section{Hasil Penelitian Terdahulu}

Studi empiris Holder, Langrehr dan Hexter (1998) dengan judul "Dividend Policy Determinants: An Investigation of the Influences of Stakeholder Theory" bertujuan untuk mengetahui pengaruh stakeholder terhadap kebijakan dividen perusahaan dengan menguji interaksi antara kebijakan dividen dan keputusan investasi perusahaan. Hasil studi ini membuktikan bahwavariabel size signifikan terhadap dividen, hal ini mengindikasikan bahwa perusahaan besar cenderung membagikan dividen lebih banya daripada perusahaan berskala kecil. Sedangkan variabel dispersion ownership mempunyai pengaruh positif dan signifikan terhadap dividen.

Chen dan Steiner (1999) dalam studi empiris yang berjudul "Managerial Ownership dan Agency Conflicts: A Nonlinier Simultaneous Equation Analysis of Managerial Ownership, Risk Taking, Debt Policy, and Dividend Policy", bertujuan untuk mengetahui hubungan managerial ownership terhadap risk-taking, kebijakan hutang dan kebijakan dividen. Hasil studi yang diperoleh menunjukkan bahwa variabel risk taking berhubungan secara positif dengan managerial ownership. Variabel 
managerial ownership berhubungan dengan risiko secara non linear. Managerial ownership juga mempunyai hubungan yang negatif terhadap debt dan dividen.

D'Souza dan Saxena (1999) melakukan penelitian yang berjudul "Agency Cost, Market Risk, Investment Opportunities and Dividend Policy - An International Perspective", dengan tujuan untuk menguji efek biaya agensi (agency cost), risiko pasar (market risk), dan kesempatan investasi (investment opportunities) terhadap kebijakan dividen pada perusahaan internasional. Hasil penelitian menunjukkan bahwa institutional holding dan beta memiliki hubungan negatif terhadap dividend payout ratio. Disisi lain, dividen payout ratio menunjukkan hubungan yang tidak signifikan terhadaps tingkat sales growth dan market to book value.

Mahadwartha (2002) dalam studi empirisnya yang berjudul "Interdependensi antara Kebijakan Leverage dengan Kebijakan Dividen: Perspektif Teori Keagenan", bertujuan menguji interdependensi antara kebijakan leverage dengan kebijakan dividen dilihat dari perspektif teori keagenan pada industri manufaktur yang terdaftar di Bursa Efek Jakarta. Hasil studi penelitian menunjukkan bahwa terdapat perbedaan empiris pengaruh variabel teori keagenan dalam interdependensi hubungan kebijakan leverage dengan kebijakan dividen di negara berkembang khususnya Indonesia dengan negara maju. Kebijakan leverage berhubungan positif dengan kebijakan dividen. Variabel kontrol size signifikan dalam menjelaskan hubungan leverage dan dividen.

Ismiyanti dan Hanafi (2003) dalam studi empirisnya yang berjudul "Kepemilikan Managerilal, Kepemilikan Institutional, Risiko, Kebijakan Hutang dan Kebijakan Dividen: Analisis Persamaan Simultan", bertujuan untuk mengetahui dan menganalisis adanya hubungan simultan antara kepemilikan manajerial, kepemilikan institusional, keputusan keuangan, kebijakan dividen dan risiko perusahaan. Hasil penelitian ini menemukan adanya hubungan interdependensi antara kebijakan kepemilikan institusional, kepemilikan manajerial, kebijakan hutang, kebijakan dividen dan risiko.

Suharli (2007) dalam studi empirisnya yang berjudul "Pengaruh Profitability dan Investment Opportunity Set terhadap Kebijakan Dividen Tunai dengan Likuiditas sebagai Variabel Penguat", bertujuan untuk menguji pengaruh profitabilitas dan kesempatan investasi terhadap kebijakan jumlah dividen kas perusahaan publik di Jakarta dengan menggunakan likuiditas sebagai variabel penguat. Hasil penelitian ini menghasilkan kesimpulan bahwa profitabilitas berpengaruh secara positif terhadap kebijakan dividen, sedangkan kesempatan investasi berpengaruh secara negatif terhadap kebijakan dividen.

Al-Malkawi (2008) dalam studi empirisnya yang berjudul "Factors Influencing Corporate Dividend Decision: Evidence from Jordanian Panel Data" bertujuan untuk menguji determinan keputusan dividen perusahaan di Jordan pada Amman Stock Exchange. Hasil penelitian ini menunjukkan bahwa variabel profitabilitas yang diukur dengan earnings per share (EPS) memiliki pengaruh yang kuat terhadap keputusan untuk membagikan dividen, temuan ini mengindikasikan bahwa perusahaan dengan tingkat keuntungan yang tinggi akan dapat memberikan dividen yang tinggi pula.

Anil dan Kapoor (2008) dalam studi empirisnya yang berjudul "Determinants of Dividend payout Ratios - A Study of Indian Information Technology Sector”, bertujuan untuk mengidentifikasi faktor-faktor yang mempengaruhi dividend payout ratio pada perusahaan Teknologi Informasi di India. Hasil penelitian ini menunjukkan bahwa terdapat hubungan positif tetapi tidak signifikan antara variabel profitability dan 
dividend payout ratio. Hubungan antara variabel liquidity dan dividend payout ratio adalah positif dan signifikan.

Kouki dan Guizani (2009) dalam studi empirisnya yang berjudul "Ownership Structure and Dividend Policy Evidence from the Tunisian Stock Market", bertujuan untuk menganalisis pengaruh struktur kepemilikan (ownership structure) terhadap kebijakan dividen pada Tunisian Stock Exchange. Hasil penelitian ini menunjukkan bahwa variabel free cash flow mempunyai hubungan positif terhadap pembayaran dividen. Institusional ownership mempunyai hubungan yang negatif dengan dividen.

Ahmed dan Javid (2009) dalam studi empirisnya yang berjudul "The Determinants of Dividend Policy in Pakistan", bertujuan untuk menguji faktor-faktor yang mempengaruhi kebijakan dividen pada 320 perusahaan non-keuangan yang terdaftar di Karachi Stock Exchange selama periode 2001 - 2006. Hasil penelitian menunjukkan bahwa terdapat hubungan yang positif dan signifikan antara variabel profitability dan dividend yield. Hal ini mengindikasikan bahwa dengan tingginya profitability serta stabilitas pendapatan perusahaan akan menghasilkan free cash flow dalam jumlah banyak untuk membayar dividen yang tinggi. Variabel ownership structure memiliki hubungan yang positif dan signifikan terhadap dividen. Variabel market to book value mempunyai hubungan yang negatif dan signifikan dengan dividen. Variabel market liquidity mempunyai pengaruh positif terhadap dividen. Variabel leverage mempunyai hubungan yang negatif dan tidak signifikan dengan dividen.

\section{KERANGKA KONSEP}

Gambar kerangka konsep dibawah ini menjelaskan bahwa dividend payout ratio perusahaan dipengaruhi oleh variabel kepemilikan manajerial, kepemilikan institusi, umur perusahaan, market to book value, growth, hutang, likuiditas, profitabilitas dan ukuran perusahaan.

\section{Gambar 1 \\ Kerangka Konsep}

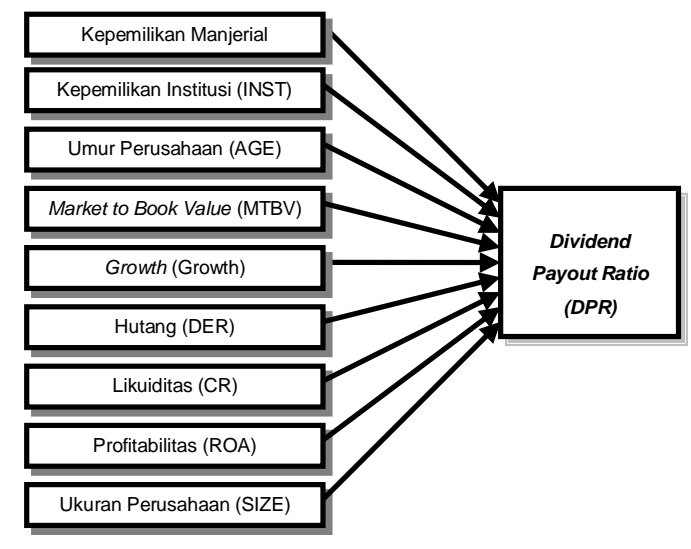

\section{Hipotesis Penelitian}

H1 : Semakin tinggi biaya agensi (yang diproksikan dengan kepemilikan manajerial dan kepemilikan institusi), kesempatan investasi (yang diproksikan dengan umur perusahaan, market to book value dan growth), hutang, likuiditas, profitabilitas, dan ukuran perusahaan mampu mendorong dividend payout ratio. 
$\mathrm{H} 2 \mathrm{a}$ : Semakin tinggi tingkat kepemilikan manajerial di dalam perusahaan, semakin rendah dividend payout ratio.

$\mathrm{H} 2 \mathrm{~b}$ : Semakin tinggi tingkat kepemilikan institusi di dalam perusahaan, semakin rendah dividend payout ratio.

$\mathrm{H} 2 \mathrm{c}$ : Semakin tinggi umur perusahaan, semakin mampu mendorong dividend payout ratio yang tinggi.

$\mathrm{H} 2 \mathrm{~d}$ : Semakin tinggi tingkat Market to book value perusahaan, semakin mampu mendorong dividend payout ratio yang tinggi.

$\mathrm{H} 2 \mathrm{e}$ : Semakin tinggi tingkat Growth perusahaan, semakin rendah dividend payout ratio.

H2f : Semakin tinggi tingkat hutang yang dimiliki perusahaan, semakin mampu mendorong dividend payout ratio yang tinggi.

$\mathrm{H} 2 \mathrm{~g}$ : Semakin tinggi tingkat likuiditas perusahaan, semakin mampu mendorong dividend payout ratio yang tinggi.

$\mathrm{H} 2 \mathrm{~h}$ : Semakin tinggi tingkat profitabilitas yang diperoleh perusahaan, semakin mampu mendorong dividend payout ratio yang tinggi.

$\mathrm{H} 2 \mathrm{i}$ : Semakin tinggi ukuran perusahaan, semakin mampu mendorong dividend payout ratio yang tinggi.

H3 : Variabel profitabilitas yang diproksikan dengan Return On Asset memberikan pengaruh dominan terhadap dividend payout ratio perusahaan.

\section{DEFINISI OPERASIONAL VARIABEL}

1. Variabel Dependen

Dividend Payout Ratio (DPR)

Dividend payout ratio (DPR) merupakan perbandingan antara jumlah dividen yang dibagikan dalam setiap lembar saham pada akhir tahun dalam satuan persen. Pengukuran ini mengacu pada penelitian D'Souza dan Saxena (1999) dan Mollah, Keasey dan Short (2000).

$\mathrm{DPR}_{\mathrm{it}}=\underline{\text { Dividend Per Share }} \times 100 \%$

Earning Per Share

\section{Variabel Independen}

\section{a. Biaya Agensi}

Biaya agensi adalah biaya yang dikeluarkan oleh principal Untuk mengatasi konflik keagenan dengan mengawasi perilaku agent agar sesuai dengan aturan yang ditentukan. Terdapat dua indikator/proksi dari variabel biaya agensi, yaitu:

1. Kepemilikan Manajerial (MOWN)

Kepemilikan manajerial adalah situasi dimana manajer memiliki saham perusahaan atau dengan kata lain manajer tersebut sekaligus sebagai pemegang saham perusahaan. Variabel ini diberi simbol MOWN, diukur dengan menggunakan dummy variabel. Menurut Mahadwartha (2002), hal ini dikarenakan data yang ada di Indonesia sifatnya binomial (ada atau tidak ada). $\mathrm{D}=1$; Perusahaan yang terdapat porsi kepemilikan manajemen (MOWN). $\mathrm{D}=0$; Perusahaan yang tidak terdapat porsi kepemilikan manajemen (nonMOWN).

2. Kepemilikan Institusi (INST) 
Institutional ownership merupakan kepemilikan oleh investor institusi seperti perusahaan asuransi, bank, perusahaan investasi dan kepemilikan institusi lain akan mendorong peningkatan pengawasan yang lebih optimal terhadap kinerja manajemen (Bathala, Moon, dan Rao, 1994). Variabel ini diberi symbol INST, yang diukur dengan presentase jumlah saham yang dimiliki oleh investor institusi. Pengukuran ini mengacu pada penelitian Chen dan Steiner (1999).

\section{INST $=$ Total saham institusi \\ Total Saham Beredar}

\section{b. Kesempatan Investasi}

Kesempatan investasi merupakan penempatan sejumlah dana dengan harapan memperoleh keuntungan dimasa yang akan datang. Terdapat tiga indikator/proksi dari variabel peluang investasi, yaitu:

1. Umur Perusahaan $(A G E)$

Variabel ini diukur dari tahun observasi dikurangi dengan tahun berdirinya perusahaan. Pengukuran ini mengacu pada penelitian Al-Malkawi (2008).

$A G E=$ Tahun observasi - Tahun berdiri

2. Market to book value (MTBV)

Market to book value merupakan perbandingan harga pasar suatu saham dengan nilai bukunya.

MTBV = Harga pasar per lembar saham

Nilai buku per lembar saham

3. Growth (Growth)

Pertumbuhan perusahaan yang sangat cepat mengindikasikan bahwa perusahaan akan lebih membutuhkan pendanaan untuk tumbuh, sehingga perusahaan lebih menyukai untuk menahanan laba daripada membayar dividen. Variabel ini diukur dengan menggunakan prosentase dari rata-rata perubahan total sales tahun 2003, 2004, 2005, 2006 dan 2007. Pengukuran ini berdasarkan penelitian Holder, Langrehr dan Hexter (1998); Chen dan Steiner (1999); D'Souza dan Saxena(1999); Anil dan Kapoor (2008); dan Ahmed dan Javid (2009).

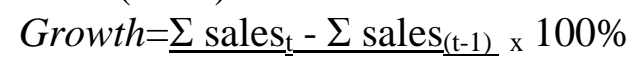

total sales $\mathrm{s}_{(\mathrm{t}-1)}$

\section{c. Hutang (Debt to Equity Ratio)}

Debt to Equity Ratio menunjukkan keseimbangan proporsi antara aktiva yang didanai oleh kreditor dan yang didanai oleh pemilik perusahaan. Variabel ini diukur dengan membagi jumlah hutang atau kewajiban dengan total modal sendiri. Pengukuran ini mengacu pada penelitian Al-Malkawi (2008).

$D E R=\underline{\text { Total Hutang atau kewajiban }}$

Total Modal sendiri

\section{d. Likuiditas (Current Ratio)}

Likuiditas merupakan kemampuan perusahaan dalam melunasi seluruh kewajiban jangka pendeknya dengan menggunakan aktiva lancar (Hanafi, 2005;36). Variabel ini diukur dengan current ratio (CR), yaitu perbandingan antara jumlah aktiva lancar dengan utang lancar. Pengukuran ini sesuai dengan penelitian Suharli (2007).

Current Ratio $=\underline{\text { Aktiva Lancar }}$ 


\section{Utang Lancar}

e. Profitabilitas (Return On Asset)

Profitabilitas merupakan tingkat keuntungan bersih yang mampu diraih oleh perusahaan pada saat menjalankan operasinya. Variabel ini di prosikan dengan Return On Asset, yaitu mengukur kemampuan perusahaan dengan keseluruhan dana yang ditanamkan dalam aktiva yang digunakan untuk operasional perusahaan untuk menghasilkan keuntungan atau menghasilkan laba bersih berdasarkan tingkat asset tertentu. Pengukuran ini sesuai dengan penelitian Chen dan Steiner (1999).

ROA $=\underline{\text { Laba bersih }}$

Total asset

\section{f. Ukuran Perusahaan (Size)}

Perusahaan besar dianggap sudah dewasa (mature) dan relatif lebih mudah untuk akses ke pasar modal (Lloyd et al.,1985 dan Vogt,1994 dalam Holder, Langrehr dan Hexter, 1998). Variabel ini diukur dengan menggunakan log natural (Ln) dari total asset. Pengukuran ini sesuai dengan penelitian Kouki dan Guizani, 2009).

Size $=$ Ln Total asset

\section{E. METODE PENELITIAN}

Jenis penelitian ini adalah penelitian eksplanasi ilmu, yang bersifat replikasi ekstensi. Obyek penelitian yang digunakan adalah perusahaan yang terdaftar sebagai perusahaan manufaktur di Bursa Efek Indonesia selama lima tahun berturut-turut, yaitu periode 2003 sampai 2007.

Populasi dalam penelitian ini adalah perusahaan manufaktur yang terdaftar di Bursa Efek Indonesia, yaitu sejumlah 151 perusahaan. Berdasarkan tehnik pengambilan sample dengan metode purposive sampling terdapat 41 perusahaan yang memenuhi kriteria. Data yang digunakan dalam penelitian ini adalah melalui data sekunder yang diperoleh dari Indonesian Capital Market Directory (ICMD) tahun 2005 dan 2008 di Pojok BEI Universitas Brawijaya.

Bedasarkan tujuan dalam penelitian ini maka model empiris yang digunakan dalam penelitian ini adalah model regresi berganda, yaitu metode yang digunakan untuk menganalisis pengaruh dari beberapa variabel independent terhadap satu variabel dependen (Ferdinand, 2006:116). Analisis data ini akan dilakukan dengan program statistik komputer SPSS versi 13.0. Bentuk dari model regresi berganda dalam penelitian ini adalah sebagai berikut:

$\mathrm{Y}=\beta_{0}+\beta_{1} \mathrm{X}_{1}+\beta_{2} \mathrm{X}_{2}+\beta_{3} \mathrm{X}_{3}+\beta_{4} \mathrm{X}_{4}+\beta_{5} \mathrm{X}_{5}+\beta_{6} \mathrm{X}_{6}+\beta_{7} \mathrm{X}_{7}+\beta_{8} \mathrm{X}_{8}+\beta_{9} \mathrm{X}_{9}+\varepsilon$

Keterangan:

$\mathrm{Y}=$ Dividend payout ratio $(D P R)$

$\beta_{0} \quad=$ Konstanta

$\beta_{1 \ldots \ldots . . .} \beta_{9} \quad=$ Koefisien Regresi

$\mathrm{X}_{1} \quad=$ Kepemilikan Manajerial $(M O W N)$

$\mathrm{X}_{2} \quad=$ Kepemilikan Institusi (INST)

$\mathrm{X}_{3} \quad=$ Umur perusahaan $(A G E)$

$\mathrm{X}_{4} \quad=$ Market to book value $(M T B V)$

$\mathrm{X}_{5} \quad=\operatorname{Growth}($ Growth $)$

$\mathrm{X}_{6} \quad=$ Hutang $(D E R)$ 


\begin{tabular}{|c|c|}
\hline $\mathrm{X}_{7}$ & $=$ Likuiditas $(C R)$ \\
\hline $\mathrm{X}_{8}$ & $=\operatorname{Profitabilitas}(R O A)$ \\
\hline$X_{0}$ & $=$ Ukuran Perusahaan $($ Size $)$ \\
\hline$\varepsilon$ & $=$ error $($ kesalahan residu $)$ \\
\hline
\end{tabular}

\section{F. HASIL PENELITIAN DAN PEMBAHASAN}

\section{Pengujian Hipotesis Satu}

Pengujian hipotesis satu digunakan untuk melihat pengaruh variabel independen secara bersama-sama terhadap variabel dependen dengan melakukan uji F statistik (uji Anova) dengan tingkat kepercayaan $(\alpha)$ sebesar 5\%. Hasil pengujian disajikan pada tabel 1berikut ini.

\section{Tabel 1}

Rangkuman Hasil Analisis Regresi

\begin{tabular}{|c|c|c|}
\hline \multicolumn{3}{|c|}{ Dependen Variabel : DPR (Y) } \\
\hline Variabel Independen & Koefisien Regresi & Prob sig \\
\hline $\operatorname{MOWN}\left(\mathrm{X}_{1}\right)$ & .073 & .520 \\
\hline INST & -.025 & .452 \\
\hline AGE & .048 & .229 \\
\hline MTBV & -.621 & .064 \\
\hline Growth & -.017 & .729 \\
\hline DER & 1.609 & $.000 *$ \\
\hline CR & 1.484 & $.011 *$ \\
\hline ROA & .006 & .922 \\
\hline SIZE & .342 & .475 \\
\hline Adjusted $\mathrm{R}^{2}: 0.105$ & & \\
\hline Konstanta $: 1.168$ & & \\
\hline$: 3.342$ & & \\
\hline$: 0.001$ & & \\
\hline
\end{tabular}

Berdasarkan tabel 1 terlihat bahwa variabel-variabel independen yang terdiri dari kepemilikan manajerial, kepemilikan institusi, umur perusahaan, market to book value, growth, hutang, likuiditas, profitabilitas, dan ukuran perusahaan mempunyai nilai $F_{\text {hitung }}$ sebesar 3.342 dengan tingkat signifikansi $F$ sebesar 0.001 dan memiliki nilai $F_{\text {tabel }}$ sebesar 2.00. Probabilitas sebesar 0.001 jauh lebih kecil dari 0.05 dan $\mathrm{F}_{\text {hitung }}>\mathrm{F}_{\text {tabel }}$ sehingga dapat disimpulkan bahwa variabel-variabel independen yang terdiri dari kepemilikan manajerial, kepemilikan institusi, umur perusahaan, market to book value, growth, hutang, likuiditas, profitabilitas, dan ukuran perusahaan berpengaruh simultan secara signifikan terhadap dividend payout ratio. Nilai adjusted $\mathrm{R}^{2}$ sebesar 0.105 menunjukkan bahwa varian variabel independen mempengaruhi varian variabel dependen sebesar $10.5 \%$, sedangkan sisanya $89.5 \%$ $(100 \%-10.5 \%)$ dijelaskan oleh variabel lain yang tidak dimasukkan dalam model.

\section{Pengujian Hipotesis Dua}

Pengujian hipotesis dua digunakan untuk melihat pengaruh variabel independen secara parsial terhadap variabel dependen dengan melakukan uji $\mathrm{t}$ statistik dengan tingkat kepercayaan $(\alpha)$ sebesar 5\%. Berdasarkan tabel 3, maka diperoleh hasil bahwa dari ke sembilan variabel independen yang dimasukkan dalam model hanya variabel DER dan CR yang signifikan pada 0.05. Sedangkan variabel 
independen lainnya MOWN, INST, AGE, MTBV, GROWTH, ROA dan SIZE tidak signifikan pada 0.05. Sehingga dapat disimpulkan bahwa DPR dipengaruhi oleh DER dan CR dengan model persamaan regresi sebagai berikut :

DPR $=1.168+0.073 X_{1}-0.025 X_{2}+0.048 X_{3}-0.621 X_{4}-0.017 X_{5}+$ $1.609 X_{6}+1.484 X_{7}+0.006 X_{8}+0.342 X_{9}$

Penjelasan dari hasil uji-t untuk masing-masing variabel adalah sebagai berikut:

a. Pengaruh Kepemilikan Manajerial Terhadap Dividend Payout Ratio Hasil penelitian ini menunjukkan bahwa arah hubungan kepemilikan manajerial perusahaan terhadap dividend payout ratio adalah positif akan tetapi tidak signifikan. Hal ini terlihat dari besarnya koefisien regresi sebesar 0.073 dan tingkat signifikansi sebesar 0.520. Hipotesis 2a yang menyatakan bahwa semakin tinggi tingkat kepemilikan manajerial di dalam perusahaan, semakin rendah dividend payout ratio, ditolak. Hasil penelitian ini sesuai dengan teori keagenan dari Jensen dan Meckling (1976) yang menyatakan bahwa masalah agensi dapat dikurangi dengan pemberian insentif, melakukan pengawasan (monitoring), meningkatkan kepemilikan manajerial, dan tindakan membatasi diri (bonding) oleh manajer. Mekanisme bonding dapat dilakukan dengan meningkatkan pembayaran dividen dan hutang. Dengan memperbesar kepemilikan saham oleh manajemen maka manajer akan berkerja sesuai dengan kepentingan pemegang saham dan mengurangi peluang manajer untuk mengambil tindakan yang menyimpang, sehingga akan memperkecil biaya agensi, dan selanjutnya akan meningkatkan kesejahteraan pemegang saham dengan meningkatkan pembayaran dividen Hasil penelitian ini konsisten dengan hasil penelitian Wahidahwati (2002:612) yang mengindikasikan bahwa bila manajer memiliki saham perusahaan yang tinggi, maka kekayaannya semakin tidak terdiversifikasi dengan baik, oleh karena itu manajer akan mengharapkan return atas opportunity cost yang lebih besar yaitu dari pembayaran dividen yang tinggi.

b. Pengaruh Kepemilikan Institusi Terhadap Dividend Payout Ratio

Hasil penelitian ini menunjukkan bahwa arah hubungan kepemilikan institusi perusahaan terhadap dividend payout ratio adalah negatif dan tidak signifikan. Hal ini terlihat dari besarnya koefisien regresi sebesar -0.025 dan tingkat signifikansi sebesar 0.452 . Hipotesis $\mathbf{2 b}$ yang menyatakan bahwa semakin tinggi tingkat kepemilikan institusi di dalam perusahaan, semakin rendah dividend payout ratio, diterima. Hasil penelitian ini mendukung teori keagenan dari Jensen dan Meckling (1976) yang menyatakan bahwa mekanisme monitoring dapat membantu mengurangi biaya keagenan. Dengan peningkatan kontrol dari pihak institusional ini akan menyebabkan kinerja manajemen diawasi secara optimal dan manajer akan menghindari perilaku yang dapat merugikan prinsipal. Pada perusahaan dengan kepemilikan institusional yang besar (lebih dari 5\%) mengindikasikan kemampuannya dalam memonitor manajemen perusahaan sehingga dapat mengurangi biaya keagenan dan akan berdampak pada pembagian dividen yang rendah. Hasil penelitian ini konsisten dengan penelitian Kouki dan Guizani (2009) yang mengindikasikan bahwa pada umumnya institutional investor adalah bank (debtholders) sehingga mereka lebih menyukai aliran kas bebas di bayarkan dalam bentuk bunga daripada membagikan dividen kepada pemegang saham lain.

c. Pengaruh Umur Perusahaan Terhadap Dividend Payout Ratio 
Hasil penelitian ini menunjukkan bahwa arah hubungan umur perusahaan terhadap dividend payout ratio adalah positif akan tetapi tidak signifikan. Hal ini terlihat dari besarnya koefisien regresi sebesar 0.048 dan tingkat signifikansi sebesar 0.229. Hipotesis 2c yang menyatakan bahwa semakin tinggi umur perusahaan, semakin mampu mendorong dividend payout ratio yang tinggi, diterima. Hasil penelitian ini mendukung mature hypothesis dari Grulon et al., (2002) dalam Al-Malkawi (2008) yang menyatakan bahwa perusahaan pada tahapan mature memiliki karakteristik pembayaran dividen yang lebih tinggi, capital expenditure yang rendah, dan umur yang relatif lebih tua. Penurunan kesempatan investasi (capital expenditure) akan berdampak pada penurunan profitabilitas dimasa mendatang serta mendorong peningkatan aliran kas bebas, sehingga akhirnya berdampak pada peningkatan pembayaran dividen. Hasil penelitian ini konsisten dengan penelitian Al Malkawi (2008:190) yang mengindikasikan bahwa perusahaan pada tahap kedewasaan (mature) akan mengalami kemunduran dalam pertumbuhan, kesempatan investasi yang lambat dan kebutuhan modal kerja cederung sedikit, sehingga hal ini akan mengakibatkan pada tersedianya free cash flow dalam jumlah banyak digunakan untuk membayar dividen.

d. Pengaruh Market to Book Value Terhadap Dividend Payout Ratio

Hasil penelitian ini menunjukkan bahwa arah hubungan market to book value terhadap dividend payout ratio adalah negatif dan tidak signifikan. Hal ini terlihat dari besarnya koefisien regresi sebesar -0.621 dan tingkat signifikansi sebesar 0.064. Hipotesis 2d yang menyatakan bahwa semakin tinggi tingkat market to book value perusahaan, semakin mampu mendorong dividend payout ratio yang tinggi, ditolak. Hasil penelitian ini mendukung hipotesis free cash flow, dimana perusahaan yang memiliki kesempatan investasi yang tinggi akan memanfaatkannya untuk menggembangkan perusahaan guna meningkatkan kesejahteraan pemegang saham. Pemanfaatan kesempatan investasi tersebut membutuhkan sumber pendanaan yang salah satunya didapat dari laba ditahan. Sehingga kesempatan investasi yang tinggi akan mendorong perusahaan untuk meningkatkan laba ditahannya. Peningkatan laba ditahan akan berdampak pada penurunan dividen yang dibayarkan. Hasil penelitian ini konsisten dengan hasil penelitian D'Souza dan Saxena (1999:39) dan Ahmed dan Javid (2009) yang menunjukkan bahwa terdapat pengaruh negatif dan tidak signifikan market to book value terhadap kebijakan dividen. Hal ini mengindikasikan bahwa perusahaan dengan tingkat rasio market to book value yang tinggi akan memiliki kesempatan investasi yang besar, sehingga jumlah dividen yang dibayarkan kepada pemegang saham rendah. Pendanaan internal dianggap lebih murah daripada pendanaan eksternal.

\section{e. Pengaruh Growth Terhadap Dividend Payout Ratio}

Hasil penelitian ini menunjukkan bahwa arah hubungan growth terhadap dividend payout ratio adalah negatif dan tidak signifikan. Hal ini terlihat dari besarnya koefisien regresi sebesar -0.017 dan tingkat signifikansi sebesar 0.729 . Hipotesis 2e yang menyatakan bahwa semakin tinggi tingkat growth perusahaan, semakin rendah dividend payout ratio, diterima. Hasil penelitian ini mendukung life cycle theory (Lease et al., 2000; Fama dan French, 2001 dalam Baker, Saadi, Dutta dan Gandhi, 2007), dimana perusahaan yang berada pada tahapan growth cenderung memiliki tingkat pembayaran dividen yang rendah, 
pertumbuhan penjualan yang tinggi, capital expenditure yang tinggi dan umur yang relatif muda. Dalam kondisi tersebut perusahaan dengan tingkat growth yang tinggi akan memiliki peluang investasi yang menguntungkan sehingga perusahaan memerlukan dana yang relatif besar. Untuk memenuhi kebutuhan dana tersebut, perusahaan akan mempertimbangkan sumber dana yang memiliki biaya modal rendah sesuai dengan ketentuan pecking order theory. Sumber dana yang diprioritaskan adalah sumber dana internal yang berasal dari laba ditahan. Semakin besar laba ditahan yang digunakan untuk membiayai investasi berarti jumlah dana yang digunakan untuk membayar dividen akan semakin kecil. Hasil penelitian ini konsisten dengan penelitian D'Souza dan Saxena (1999:39) yang mengindikasikan bahwa perusahaan dengan pertumbuhan cepat akan lebih membutuhkan pendanaan untuk tumbuh, sehingga perusahaan lebih menyukai untuk menahanan laba daripada membayar dividen.

\section{f. Pengaruh Hutang (Debt to Equity Ratio) Terhadap Dividend Payout Ratio}

Hasil penelitian ini menunjukkan bahwa arah hubungan hutang (DER) terhadap dividend payout ratio adalah positif dan signifikan. Hal ini terlihat dari besarnya koefisien regresi sebesar 1.609 dan tingkat signifikansi sebesar 0.000. Hipotesis 2f yang menyatakan bahwa semakin tinggi tingkat hutang yang dimiliki perusahaan, semakin mampu mendorong dividend payout ratio yang tinggi, diterima. Hasil ini mendukung free cash flow hypothesis, yang menyatakan bahwa hutang merupakan salah satu cara untuk mengurangi konflik keagenan. Dengan menggunakan hutang maka manajer akan dipaksa untuk mengeluarkan aliran kas yang berlebihan dari perusahaan untuk membayar bunga hutang dan pokok pinjamannya. Penurunan aliran kas akan menyebabkan berkurangnya kas yang ada pada manajer, sehingga keadaan ini akan membatasi (bonding mechanism) keinginan manajer menggunakan aliran kas untuk menambah pendapatan mereka dan melakukan investasi yang berlebihan (over investment). Hasil penelitian ini konsisten dengan penelitian Mahadwartha (2002:26) yang menunjukkan hasil bahwa kebijakan hutang berhubungan positif dan signifikan terhadap kebijakan dividen. Hasil ini mengindikasikan bahwa perusahaan yang membagikan dividen dalam jumlah besar maka dalam membiayai investasinya akan diperlukan tambahan dana melalui hutang. Lebih lanjut lagi menurut Miller (1977) dalam Mahadwartha (2002), leverage yang tinggi dapat berarti bahwa risiko perusahaan meningkat (biaya kebangkrutan), sehingga shareholders memerlukan tambahan return untuk kompensasi tambahan risiko tersebut. Tambahan return tersebut diperoleh dari dividen. Hal ini adalah perilaku rasional yang merupakan asumsi dasar perilaku dalam berinvestasi. Dari beberapa pernyataan di atas, dapat disimpulkan bahwa perusahaan manufaktur di Indonesia lebih memilih untuk membagikan dividen yang tinggi. Dividen yang tinggi berarti perusahaan akan lebih banyak menggunakan hutang dalam membiayai investasinya sehingga untuk memberikan kompensasi tambahan akibat naiknya risiko bisnis perusahaan karena tingginya hutang maka perusahaan akan membagikan return berupa dividen kepada pemegang saham. Hal ini berarti bahwa perusahaan manufaktur di Indonesia selalu menjaga struktur modal optimalnya relatif tetap.

g. Pengaruh Likuiditas (Current Ratio) Terhadap Dividend Payout Ratio Hasil penelitian ini menunjukkan bahwa arah hubungan likuiditas (CR) terhadap dividend payout ratio adalah positif dan signifikan. Hal ini terlihat dari besarnya 
koefisien regresi sebesar 1.484 dan tingkat signifikansi sebesar 0.011. Hipotesis 2g yang menyatakan bahwa semakin tinggi tingkat likuiditas perusahaan, semakin mampu mendorong dividend payout ratio yang tinggi, diterima. Hasil penelitian ini konsisten dengan penelitian Suharli (2007), Anil dan Kapoor (2008) dan Ahmed dan Javid (2009) yang menunjukkan bahwa variabel liquidity dan dividend payout ratio adalah positif dan signifikan. Hal ini mengindikasikan bahwa perusahaan dengan likuiditas yang baik akan meningkatkan kemampuan perusahaan untuk membayar dividen.

h. Pengaruh Profitabilitas (Return On Asset) Terhadap Dividend Payout Ratio Hasil penelitian ini menunjukkan bahwa arah hubungan profitabilitas (ROA) terhadap dividend payout ratio adalah positif akan tetapi tidak signifikan. Hal ini terlihat dari besarnya koefisien regresi sebesar 0.006 dan tingkat signifikansi sebesar 0.922. Hipotesis $\mathbf{2 h}$ yang menyatakan bahwa semakin tinggi tingkat profitabilitas yang diperoleh perusahaan, semakin mampu mendorong dividend payout ratio yang tinggi, diterima. Hasil penelitian ini mendukung teori signaling (Bhattacharya,1979) yang menyatakan bahwa perusahaan dengan pertumbuhan laba yang baik akan menjadi sinyal bagi investor tentang prospek dimasa mendatang serta kemampuan perusahaan dalam membagikan dividen. Hasil penelitian ini konsisten dengan penelitian Suharli (2007), Al Malkawi (2008), Anil dan Kapoor (2008) dan Ahmed dan Javid (2009) yang mengindikasikan bahwa pihak manajemen akan membayarkan dividen untuk memberi sinyal mengenai keberhasilan perusahaan membukukan profit, sinyal tersebut menyimpulkan bahwa kemampuan perusahaan untuk membayar dividen merupakan fungsi dari keuntungan. Dengan demikian profitabilitas mutlak diperlukan untuk perusahaan apabila hendak membayarkan dividen.

\section{i. Pengaruh Ukuran Perusahaan (Size) Terhadap Dividend Payout Ratio}

Hasil penelitian ini menunjukkan bahwa arah hubungan ukuran perusahaan (size) terhadap dividend payout ratio adalah positif akan tetapi tidak signifikan. Hal ini terlihat dari besarnya koefisien regresi sebesar 0.342 dan tingkat signifikansi sebesar 0.475 . Hipotesis $2 \mathbf{i}$ yang menyatakan bahwa semakin tinggi ukuran perusahaan, semakin mampu mendorong dividend payout ratio yang tinggi, diterima. Hasil penelitian ini konsisten dengan penelitian Al-Malkawi (2008) yang menunjukkan bahwa variabel size mempunyai pengaruh positif terhadap keputusan dividen, temuan ini mengindikasikan bahwa perusahaan dengan tingkat total asset yang tinggi akan dapat memberikan dividen yang tinggi pula. Perusahaan besar (mature) cenderung untuk membagikan dividen dalam jumlah tinggi daripada perusahaan kecil karena perusahaan besar relatif mudah memenuhi sumber dana dari hutang melalui pasar modal.

\section{Pengujian Hipotesis Tiga}

Untuk menguji hipotesis yang berpengaruh dominan, digunakan alat uji koefisien standardized atau beta $(\beta)$. Keuntungan dengan menggunakan koefisien standardized beta adalah mampu mengeliminasi perbedaan unit ukuran pada variabel independen (Ghozali, 2006:88). Besarnya $\alpha$ yang digunakan adalah sebesar $5 \%$.

Hipotesis tiga menyatakan bahwa variabel profitabilitas (ROA) akan memberikan pengaruh dominan terhadap dividend payout ratio perusahaan. Berdasarkan tabel 5.6 di atas, maka dapat dilihat bahwa variabel DER memiliki nilai koefisien standardized beta yang paling besar diantara variabel independen lainnya, 
yaitu sebesar 0.440 dengan tingkat signifikansi sebesar 0.000. Sehingga dapat disimpulkan bahwa variabel DER memberikan pengaruh dominan terhadap dividend payout ratio perusahaan, bukan variabel profitabilitas (ROA). Hal ini disebabkan karena perbedaan proksi dari variabel profitabilitas yang digunakan, dimana pada penelitian Al Malkawi (2008) menggunakan earning per share sebagai proksi dari variabel profitabilitas, sedangkan pada penelitian ini menggunakan return on asset sebagai proksi dari variabel profitabilitas.

\section{F. KESIMPULAN}

Berdasarkan tujuan penelitian dan pembahasan yang dijelaskan pada bab sebelumnya, maka dari penelitian ini dapat diambil suatu kesimpulan sebagai berikut:

1. Tingkat kepemilikan manajerial, kepemilikan institusi, umur perusahaan, market to book value, growth, hutang, likuiditas, profitabilitas, dan ukuran perusahaan secara bersama-sama mampu mendorong dividend payout ratio.

2. Tingkat kepemilikan manajerial, umur perusahaan, likuiditas, profitabilitas, dan ukuran perusahaan mampu mendorong dividend payout ratio yang tinggi. Sedangkan tingginya kepemilikan institusi, market to book value, growth justru dapat menurunkan dividend payout ratio.

3. Tingkat hutang sangat berperan dalam mendorong dividend payout ratio yang tinggi. 


\section{DAFTAR PUSTAKA}

Ahmed, Hafeez dan Attiya Y. Javid. 2009. The Determinants of Dividend Policy in Pakistan. International Research Journal of Finance and Economics.

Al-Malkawi, Husam-Aldin Nizar. 2008. Factors Influencing Corporate Dividend Decision: Evidance from Jordanian Panel Data. International Journal of Business.

Anil, Kanwal dan Sujata Kapoor. 2008. Determinants of dividend Payout Ratio - A Study of Indian information Technology Sector. International Research Journal of Finance and Economics.

Baker, H. Kent, Samir Saadi, Shantanu Dutta, dan Devinder Gandhi. 2007. The perception of dividends by Canadian Managers: new survey evidence. International Journal of Managerial Finance 3 (1).

Bathala, C.T., K.P. Moon, dan R.P. Rao. 1994. Managerial ownership, debt policy, and the impact of institutional holding: an agency perspective. Financial Management 23, 38-50.

Brigham, Eugene F. Dan Joel F. Houston. 2001. Fundamentals of Financial Management, $8^{\text {th }}$. Dodo Suharto dan Herman Wibowo (penerjemah). Manajemen Keuangan. Erlangga.

Chen, Carl R. dan Thomas L. Steiner. Februari 1999. Managerial Ownership dan Agency Conflicts: A Nonlinier Simultaneous Equation Analysis of Managerial Ownership, Risk Taking, Debt Policy, and Dividend Policy. The Financial Review. Vol. 34, No. 1.

Ferdinand, Augusty. 2006. Metode Penelitian Manajemen. Edisi 2. Badan Penerbit Universitas Diponegoro Semarang.

Ghozali, Imam. 2006. Aplikasi Analisis Multivariate Dengan Program SPSS. Cetakan IV. Badan Penerbit Universitas Diponegoro Semarang.

Hanafi, Mamduh M. 2004. Manajemen Keuangan. Edisi 2004/2005. BPFE-UGM Yogyakarta.

Holder, Mark E., Frederick W. Langrehr, dan J. Lawrence Hexter. 1998. Dividend Policy Determinants: An Investigation of the Influences of Stakeholder Theory. Financial Management 27 (3):73-82

Ismiyanti, Fitri dan Mamduh M. Hanafi. Oktober 2003. Kepemilikan Managerilal, Kepemilikan Institutional, Risiko, Kebijakan Hutang dan Kebijakan Dividen: Analisis Persamaan Simultan. Simposium Nasional Akuntansi VI

Jensen, Michael C. Mei 1986. Agency Cost of Free Cash Flow, Corporate Finance, and Takeovers. American economic Review. Vol. 76, No. 2, p.323-329. 
Kouki. Mondher dan Moncef Guizani. 2009. Ownership Structure and Dividend Policy Evidence from the Tunisian Stock Market. European Journal of Scientific Research 25 (1): 42-53.

Mahadwarta, Putu Anom. April 2002. Interdependensi antara Kebijakan Leverage dengan Kebijakan Dividen: Perspektif Teori Keagenan. Jurnal Riset Akuntansi, Manajemen dan Ekonomi STIE Yogyakarta.

Mollah, Sabur, Kevin Keasey dan Helen Short. Mei 2000. The Influence of Agency Costs on Dividend Policy in an Emerging Market: Evidence from the Dhaka Stock Exchange. Paper of workshop at the University of Oslo Norway.

Suharli, Michell. Mei 2007. Pengaruh Profitability dan Investment Opportunity Set terhadap kebijakan Dividen Tunai dengan Likuiditas Sebagai variabel Penguat. Jurnal Akuntansi Keuangan 9 (1)

Wahidahwati. September 2002. Kepemilikan Manajerial dan Agency Conflicts: Analisis Persamaan Simultan Non Linear dari Kepemilikan Manajerial, Penerimaan Risiko (Risk Taking), kebijakan Hutang dan Kebijakan Dividen. Simposium Nasional Akuntansi 5 Semarang. 